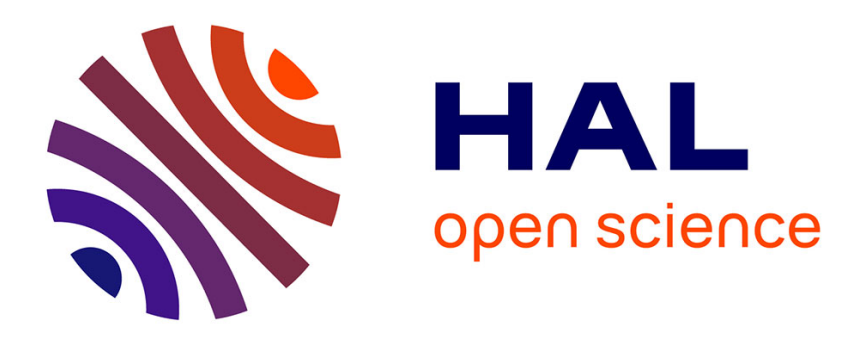

\title{
Characteristics of honey bee colonies (Apis mellifera) in Sweden surviving Varroa destructor infestation
}

\author{
Barbara Locke, Ingemar Fries
}

\section{To cite this version:}

Barbara Locke, Ingemar Fries. Characteristics of honey bee colonies (Apis mellifera) in Sweden surviving Varroa destructor infestation. Apidologie, 2011, 42 (4), pp.533-542. 10.1007/s13592-011-0029-5 . hal-01003560

\section{HAL Id: hal-01003560 https://hal.science/hal-01003560}

Submitted on 1 Jan 2011

HAL is a multi-disciplinary open access archive for the deposit and dissemination of scientific research documents, whether they are published or not. The documents may come from teaching and research institutions in France or abroad, or from public or private research centers.
L'archive ouverte pluridisciplinaire HAL, est destinée au dépôt et à la diffusion de documents scientifiques de niveau recherche, publiés ou non, émanant des établissements d'enseignement et de recherche français ou étrangers, des laboratoires publics ou privés. 


\title{
Characteristics of honey bee colonies (Apis mellifera) in Sweden surviving Varroa destructor infestation
}

\author{
Barbara LOCKE, Ingemar FRIES \\ Department of Ecology, Swedish University of Agricultural Sciences, P.O. Box 7044, 75007 Uppsala, Sweden
}

Received 7 June 2010 - Revised 7 October 2010 - Accepted 13 October 2010

\begin{abstract}
A population of European honey bees (Apis mellifera) surviving Varroa destructor mite infestation in Sweden for over 10 years without treatment, demonstrate that a balanced host-parasite relationship may evolve over time. Colony-level adaptive traits linked to Varroa tolerance were investigated in this population to identify possible characteristics that may be responsible for colony survival in spite of mite infestations. Brood removal rate, adult grooming rate, and the mite distribution between brood and adults were not significantly different in the untreated population compared with treated control colonies. However, colony size and the reproductive success of the mite were significantly reduced in surviving colonies compared with control colonies. Our data suggest that colony-level adaptive traits may limit mite population growth by reducing mite reproduction opportunities and also by suppressing the mite reproductive success.
\end{abstract}

\section{Varroa destructor / Apis mellifera / natural selection / tolerance / host-parasite interaction}

\section{INTRODUCTION}

Host-parasite interactions in social insects are intricate with two different levels in which social insects can defend themselves against parasites: (1) by innate individual-level immune responses and (2) by adaptive colonylevel defence mechanisms. At the individual level, the immune system of the European honey bee, Apis mellifera, is not welldeveloped compared with other insects (Evans et al. 2006), and rather, they rely heavily on colony-level adaptive mechanisms for defence. The parasitic Varroa destructor mite has become a major threat to apiculture with European races of $A$. mellifera throughout most of the world in contrast to the African honey bee race A. mellifera scutellata and the Africanized bees in South America (Rosenkranz et al. 2010).

Corresponding author: B. Locke, barbara.locke@ekol.slu.se Manuscript editor: David Tarpy
By feeding on the hemolymph of adult bees (during their phoretic phase) and developing bees (during their reproductive phase), the mite vectors naturally occurring otherwise latent viruses which can develop into severe overt infections and potentially lead to colony mortality (Allen and Ball 1996; Nordström et al. 1999; Martin 2001; Sumpter and Martin 2004).

Mite control methods, which are used in apiculture to limit the mite population and avoid colony losses, can be problematic for several reasons. Chemical residues can build up in hive products (Bogdanov et al. 1998; Wallner 1999); mites can develop resistance to effective acaricides (Sammataro et al. 2005); some methods cause damage to bees (Imdorf et al. 1990, 1999; Charrièr and Imdorf 2002), but most importantly, they remove the selective pressures on the mites and the host that may otherwise produce a stable host-parasite relationship through co-adaptive evolution (Fries and Camazine 2001). 
A stable host-parasite relationship is seen between the mite and its natural host, the Asian honey bee, Apis cerana. In this system, through a long evolutionary process, the Asian honey bee has adapted unique colony-level defence mechanisms, such as preventing mite reproduction in worker brood and entombing mites in drone brood, thereby limiting the mite population growth to a tolerable level where colony mortality rarely occurs (reviewed in Rath 1999). The Africanized honey bees in South America, descendants of $A$. mellifera scutellata, also exhibit tolerance to $V$. destructor and a variety of defence mechanisms, such as behavioural traits (CorrêaMarques and De Jong 1998; Boecking and Spivak 1999; reviewed in Rosenkranz 1999) and reduced mite reproductive ability (Medina et al. 2002; Martin and Medina 2004; Mondragon et al. 2006) have been reported to explain their survival without mite control treatments. In addition, in the African bee race A. mellifera scutellata, the bees and/or the mites have adapted to a stable host-parasite relationship within 56 years from exposure (Allsopp et al. 1997; Allsopp 2006). These African and Africanized hybrid bees may have different genetic or environmental advantages for Varroa tolerance compared with the European races of A. mellifera, but their tolerance mechanisms are still unclear. Breeding programmes, with efforts to produce mite-tolerant strains of European honey bee races, have had some success most notably with bees expressing the Varroa-sensitive hygiene trait (Harbo and Harris 2005; Ibrahim and Spivak 2006) and bees of the Russian-hybrid stock (Rinderer et al. 2001), yet mite population monitoring and mite control treatments are still required for the survival of these bees (Tarpy et al. 2007).

There have been reports on populations of European honey bee races surviving mite infestation for long periods without mite control treatment (De Jong and Soares 1997; Kefuss et al. 2004; Fries et al. 2006; Le Conte et al. 2007; Seeley 2007), however little has been described concerning their tolerance mechanisms or colony characteristics. In an attempt to consider both the host and the parasite in co-adaptation processes, Fries and Bommarco (2007) demonstrated that mite tolerance in one of these surviving populations is a product of adapted traits of the bees and not of the mites. This could be the case for other surviving populations in Europe because of the low genetic variation in European mites, due to their clonal origin (Solignac et al. 2005). These surviving populations may hold an answer to the selective process of achieving a stable relationship between $A$. mellifera and $V$. destructor and give insight into colony-level adaptations of mite infestation.

The objective of this study was to unravel the mechanisms responsible for the increased mite tolerance in a population of surviving European honey bee colonies in Sweden on the island of Gotland in the Baltic Sea. This population was established as part of a natural selection experiment called the "Bond-Project" and has survived since 1999 without mite control or beekeeping management and with exposure to severe mite infestation selection pressure. For a more detailed explanation on the background of these surviving honey bee colonies, refer to Fries et al. (2003; 2006) and Fries and Bommarco (2007).

This study was an exploratory investigation of colony-level characteristics that have been linked to, or suggested to be important for, mite tolerance in European races of honey bees. These characteristics include: (1) hygienic behaviour, the ability of honey bees to detect and remove mite-infested brood (Spivak 1996; Spivak and Reuter 2001); (2) grooming of adult bees, a behaviour resulting in capturing and damaging of adult mites (Moosbeckhofer 1992; Moretto et al. 1995); (3) colony size and temporal dynamics, a characteristic known to greatly influence the mite population given the importance of brood amounts for mite reproduction (Fries et al. 1994; Calis et al. 1999); (4) brood attractivity, measured by the distribution ratio of mites on adult bees (phoretic mites) and in the brood (reproducing mites), can influence the proportion of reproducing mites in the colony and therefore the growth rate (Boot et al. 1993) and (5) suppression of mite reproductive ability and success, an important parameter able to greatly affect the mite population (Fries et al. 1994; Rosenkranz and Engels 1994). 


\section{MATERIALS AND METHODS}

The study was conducted from June through September in 2008 and 2009. The population of surviving honey bee colonies $(N=14)$ was studied in a single apiary on the southern part of the island Gotland, Sweden, with the mite-susceptible control colonies $(N=12)$ in an apiary approximately $20 \mathrm{~km}$ away. A second apiary was established in Uppsala, Sweden, in 2009, with colonies headed with queens produced and mated within the population of the surviving colonies on Gotland $(N=7)$ and with a control group $(N=7)$ in the same apiary.

The control apiary on Gotland was effectively treated for mites in the autumn of 2007 and therefore had only a few mites during the 2008 season. The control colonies were not treated in 2008 so the mite population was able to increase during 2009. Every measurement was compared with control colonies at the same time except for grooming behaviour in 2008 since no mites were available in the control colonies to examine. The surviving colonies were sometimes weak or did not have brood due to supersedure and therefore the actual number of colonies examined varied for different traits at each visit.

\subsection{Hygienic behaviour}

On Gotland in 2008, hygienic behaviour was tested in surviving and control colonies in June, July and August, and again in July 2009, both in Uppsala and on Gotland. One hundred pupae in each colony were marked and pin-killed (Palacio et al. 2000) while 100 cells in the same brood area were marked without pin-killing, for control. The proportion of removed killed pupae was recorded at 12 and $24 \mathrm{~h}$ after pinning to determine hygienic behaviour expressed as the brood removal rate. Every test was conducted on the surviving colonies and control colonies on the same day and approximately at the same time of the day.

\subsection{Grooming behaviour}

Grooming behaviour was tested in surviving colonies in June, July and August of 2008 on Gotland and in surviving and control colonies in August 2009 in Uppsala. Bottom-board metal slide-in trays were used to collect colony debris and remained under the colony for 7 days before examination. The proportion of damaged mites in colony debris was recorded in surviving colonies and in control colonies to determine the adult bee grooming rate or grooming behaviour (Bienefeld et al. 1999).

\subsection{Colony size and temporal dynamics}

Colony size was measured in surviving and control colonies on Gotland in June, July and August of 2008, July, August and September of 2009 and in August of 2009 in Uppsala. Population estimates of the adult bees, worker brood and drone brood were made using the Liebefeld Estimation Method (Imdorf et al. 1987) to determine colony size and analysed over time to determine temporal dynamics of colony size.

\subsection{Brood attractivity and Varroa mite infestation and distribution}

Samples for determining mite infestation rates were taken on the same dates as colony size measurement. The phoretic Varroa mite infestation rates were determined by washing samples of around 200 bees in each sample with soapy water to dislodge the mites to count them as a sample proportion (De Jong et al. 1982; Fries et al. 1991a). Adult bees were collected from the brood chamber of the hive. The Varroa infestation rates in worker brood were calculated as the proportion of infested cells in a sample. This was measured when cells were opened for examination of mite reproduction or otherwise by opening 100 randomly selected pupal cells in the field (Fries et al. 1991b). The number of mites on adults in the colony was calculated by multiplying the infestation rates of adults by the number of adult bees in the colony. Using colony brood estimations, the same procedure was done to calculate the number of mites in brood. The total number of mites on adults and in brood was added together to produce the total number of mites in the colony. The mite distribution was then determined as proportions of mites on either adult bees or in brood of the total mite population within the colony. The mite distributions were used to determine the effect of brood attractivity. 


\subsection{Suppression of mite reproductive success}

Mite reproductive parameters were recorded in surviving colonies in August 2008 on Gotland with control colonies in Uppsala recorded in July 2008. In 2009, records were made both in surviving and control colonies on Gotland in July and in Uppsala in August. Sealed worker brood cells containing pupae older than approximately $190 \mathrm{~h}$ (brown eyes and yellow body stage, according to Martin 1994) were carefully opened and pupae removed in the laboratory. The developmental stage of each pupa was recorded based on the appearance description given by Martin (1994). Complete mite families from single-mother mite-infested cells were removed using a fine brush and examined under a stereo microscope.

Within each pupal cell, the following information was collected:

1. Whether the mother mite reproduced,

2. The total number of offspring per mother mite,

3. Whether an alive male was present or absent,

4. The number of dead mite progeny, and

5. The developmental stage of each individual mite offspring.

The collected information was then used to determine the reproductive success measured as the ability of the mother mite to produce at least one viable mated female offspring at the time the developing bee hatches from the cell. The information collected was further used to explain fecundity and which parameter that was most often responsible for any reproductive failure. Such failure could depend on infertility, absence of male offspring, high proportion of mite offspring mortality, or delayed egg-laying by the mother mite.

The yellow thorax stage of the pupae is the longest stage ranging from approximately $190-240 \mathrm{~h}$, and the male mite does not become adult until about $210 \mathrm{~h}$ (Martin 1994). Therefore, any yellow thorax-stage recording where no adult male mite was observed was recorded as uncertain since immature male mites are difficult to distinguish from early developing female mite offspring. A total of 22 cells in the control population and 24 cells in the surviving population were considered uncertain and were therefore not included in the analysis. For each colony examined, the proportions of the different reproductive parameters were used in the statistical analysis. In the surviving population, a total of 614 cells were examined in 23 colonies, and a total of 592 cells were examined in the 21 control colonies with observations between ten and 35 cells per colony.

\subsection{Statistical analysis}

All statistical analyses were performed in SAS 9.1 for Windows.

We used linear repeated-measures mixed-effects models (SAS proc Mixed) to independently test the effects that surviving colonies compared with control colonies (treatment groups) had on brood removal rate (hygienic behaviour), adult grooming rate (grooming behaviour), colony size, mite infestation, mite distribution (brood attractivity) and the proportion of successfully reproducing mites (along with the various parameters measured to determine mite reproductive success). The covariance structure for the repeated factor was selected based on the Aikaike's information criteria (Littell et al. 1996).

In order to test for all possible effects, we started by analysing full models including all possible explanatory variables such as treatment, mite infestation, colony, date and location. Non-significant variables $(P>0.05)$ were sequentially excluded from the model starting with the higher order of interactions while factors that were significant or part of significant interactions were kept in the model (Crawley 2002). The assumption of normality and equal variance were verified by analysis of residuals (Littell et al. 1996). The Satterthwaite method was used to approximate denominator degrees of freedom in all models (Littell et al. 1996). Correlation analysis was used to compare the variation in colony size due to mite infestation rates.

\section{RESULTS}

\subsection{Hygienic behaviour}

Brood removal rates at 12 and $24 \mathrm{~h}$ did not differ significantly $(P>0.05)$ at $12 \mathrm{~h}$ between control colonies, $0.15 \pm 0.02(\bar{x} \pm \mathrm{SE}, n=34)$ and surviving colonies, $0.20 \pm 0.04(\bar{x} \pm \mathrm{SE}, n=$ 34 ), or at $24 \mathrm{~h}$ between control colonies, $0.49 \pm$ 
$0.05(\bar{x} \pm \mathrm{SE}, n=34)$ and surviving colonies, $0.46 \pm 0.05(\bar{x} \pm \mathrm{SE}, n=34)$. No other variables included in the model had any significant effect on the hygienic behaviour $(P>0.05)$.

\subsection{Grooming behaviour}

The adult bee grooming rate in 2008 was only measured on mites from the surviving colonies, $0.31 \pm 0.02(\bar{x} \pm \mathrm{SE}, n=1174)$, since no mites were found in the control group that year. In the Uppsala apiary in 2009, the proportion of damaged mites in surviving colonies, $0.36 \pm 0.04(\bar{x} \pm \mathrm{SE}, n=135)$ was not significantly different $(P>0.05)$ than in the control colonies, $0.46 \pm 0.04(\bar{x} \pm \mathrm{SE}, n=109)$. No other variables included in the model had any significant effect on the grooming behaviour $(P>0.05)$.

\subsection{Colony size and temporal dynamics}

Colony size measurements were significantly reduced in the surviving colonies compared with control colonies (adult bees, $F_{1}, 56.7=$ 28.94, $P<0.0001$, Figure 1a; worker brood, $F_{1,42.7}=7.81, P=0.0078$ Figure $1 \mathrm{~b}$ and drone brood, $F_{1}, 21.5=10.35, P=0.0040$, Figure 1c). Date also had a significant effect on colony size (adult bees, $F_{4}, 64.7=6.23, P=0.0003$; worker brood, $F_{4}, 78.6=8.65, P<0.0001$ and drone brood, $\left.F_{4}, 83.7=7.91, P<0.0001\right)$, however the two populations showed significantly different temporal dynamics between adult bees and drone brood production but not for worker brood production (adult bees, $F_{4}, 68.9=3.72$, $P=0.0085$; drone brood, $F_{4}, 84.4=3.11, P=$ 0.0193; Figure 1). In 2008, the mite infestation rates in the surviving colonies on adult bees for June, $0.02 \pm 0.004(\bar{x} \pm \mathrm{SE}, n=12)$; July, $0.05 \pm$ $0.03(\bar{x} \pm \mathrm{SE}, n=6)$ and August, $0.07 \pm 0.03$ $(\bar{x} \pm \mathrm{SE}, n=12)$ did not correlate significantly with the number of adult bees in the colonies $(R=-0.23 ; n=30 ; P>0.05)$. The mite infestation rates in the worker brood of the surviving colonies in June $0.09 \pm 0.03(\bar{x} \pm \mathrm{SE}, n=12)$; July, $0.09 \pm 0.03(\bar{x} \pm \mathrm{SE}, n=6)$ and August,
$0.17 \pm 0.04(\bar{x} \pm \mathrm{SE}, n=12)$ of 2008 , also did not correlate with the number of worker brood production $(R=-0.33 ; n=30 ; P>0.05)$. Therefore, the reduced colony size in the surviving population was not an effect of mite infestation.

\subsection{Brood attractivity and Varroa mite infestation and distribution}

Date significantly affected the number of mites within the colonies $\left(F_{1}, 57.2=13.54, P<\right.$ $0.0001)$. In 2008, no mites were recorded in the control colonies, although by July 2009, the average mite infestation rates in adults, $0.05 \pm$ $0.01(\bar{x} \pm \mathrm{SE}, n=13)$ and in brood $0.12 \pm 0.03$ $(\bar{x} \pm \mathrm{SE}, n=13)$ were similar to those of the surviving colonies (adult, $0.07 \pm 0.02$; brood, $0.13 \pm 0.03 ; \bar{x} \pm \mathrm{SE}, n=11)$. The mite population growth rate measured on adult bees over time from July to September 2009 was significantly faster in the control colonies compared with surviving colonies $\left(F_{4}, 60.9=5.59, P=0.0007\right.$, Figure 2). During the summer of 2009, the adult bee mite infestation rates were significantly correlated with the number of adult bees in the control colonies $(R=-0.62 ; n=30 ; P>0.001)$, and mortality occurred in all these colonies by the following winter. In contrast to 2008, there was a correlation between the adult bee mite infestation rates and the number of adult bees in the surviving population in $2009(R=-0.45$; $n=$ $37 ; 0.001<P<0.01)$. However the surviving population survived the winter.

The distribution of mites between adult bees and brood did not show any significant difference $(P>0.05)$ between the surviving colonies and control colonies.

\subsection{Suppression of mite reproductive success}

A highly significant difference was observed in the average proportions of successfully reproducing Varroa mites between the surviving colonies $0.48 \pm 0.02(\bar{x} \pm \mathrm{SE}, n=23)$ and the control colonies $0.78 \pm 0.02(\bar{x} \pm \mathrm{SE}, n=21$, $F_{1,41.4}=75.78, P<0.0001$, Figure 3$)$. Individu- 


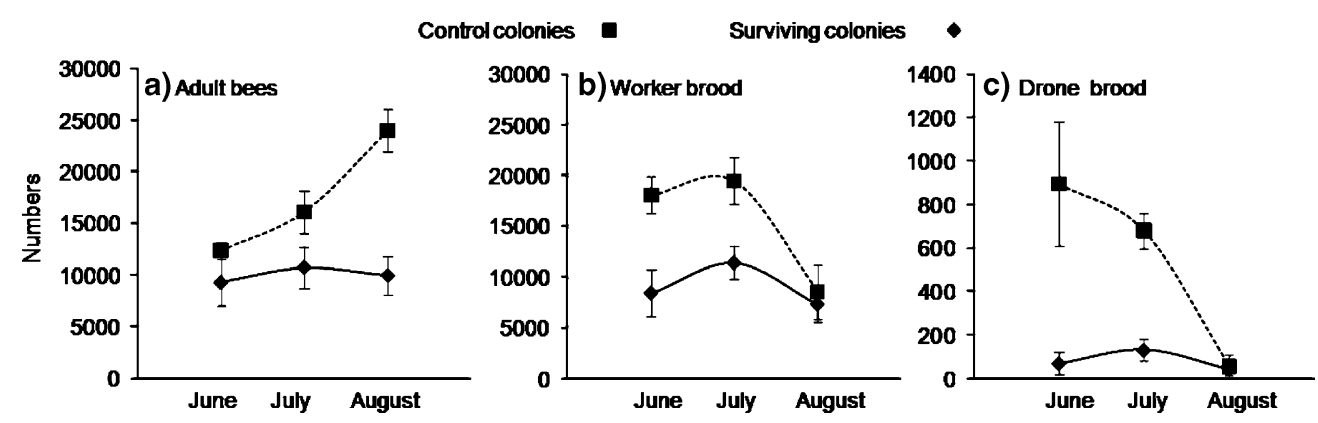

Figure 1. Mean colony size estimations on the number of $\mathbf{a}$ adult bees, $\mathbf{b}$ worker pupae and $\mathbf{c}$ drone brood, with standard error bars, in 2008, for surviving honey bee colonies (solid line) through June $(n=12)$, July ( $n=6)$ and August $(n=12)$, and for control colonies (dotted line) through June $(n=10)$, July $(n=4)$ and August $(n=4)$ on Gotland.

ally, each parameter investigated for determining the proportion of mites successfully reproducing was significantly different between the surviving population and the control population (Table I). The fecundity of the mother mites, excluding mites that did not reproduce, was also significantly different between the two populations (Table I).

\section{DISCUSSION}

Our results clearly demonstrate a significant reduction in the reproductive success of Varroa mites (measured as the ability to produce at least one viable offspring) in a European population of A. mellifera colonies where no mite control was practiced for more than 10 years. The surviving colonies had on average almost twice the proportion of infertile mites, more than twice the proportion of dead progeny, significantly reduced fecundity and an overall reproductive success rate of less than $50 \%$ compared with over $75 \%$ in control colonies. Delayed egglaying by the mother mites was proportionally the most frequent cause of reproductive failure with dead progeny as the second most common cause. Reduced fecundity, along with the reduced ability to produce viable female offspring clearly, is important to explain the lower mite infestation rates in the surviving population.

Although differences were small, mite infertility was significantly different between the surviving and control populations in this study. This result contrasts the observations by Rosenkranz et al. (2009) who were unable to show a difference
Figure 2. Regression lines on the mean mite infestation rates (number of mites per 200 adult bees) with standard error bars, in 2009, of surviving colonies (solid line; $y=0.15 x-$ $0.12)$ through July $(n=13)$, August $(n=11)$ and September $(n=13)$, and for control colonies (dotted line; $y=0.51 x-0.45)$ through July $(n=11)$, August $(n=11)$ and September $(n=8)$ on Gotland.

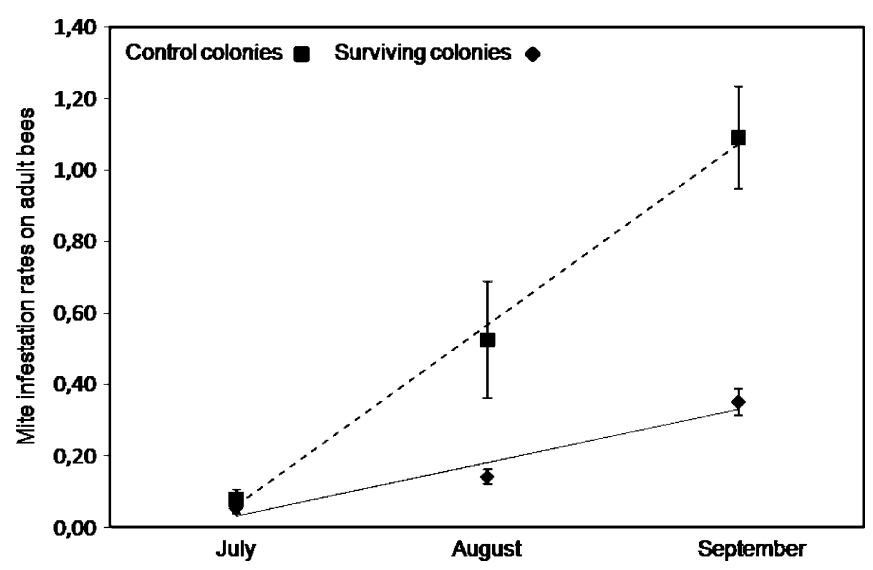




\section{Surviving colonies}

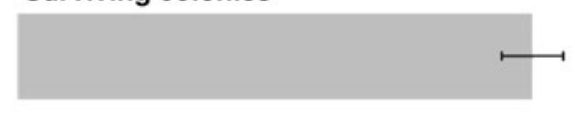

Control colonies

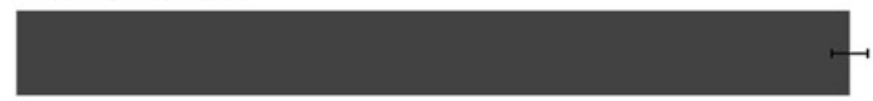

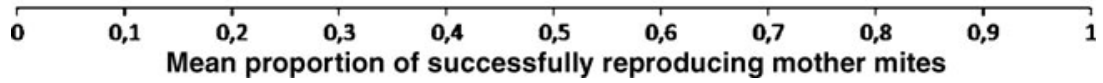

Figure 3. Mean proportions of mother mites producing viable mated female offspring in surviving $(n=23)$ and control colonies $(n=21)$ with standard error bars.

in mite infertility between different European honey bee races, surviving honey bees from Gotland or bees selected for Varroa-sensitive hygienic behaviour. However, Rosenkranz et al. (2009) were able to find different cuticular compounds on the bees in their study which could possible reduce (Millani et al. 2004), or stimulate (Garrido and Rosenkranz 2003; 2004), $V$. destructor reproduction in different ways including the fertility, fecundity, egg-laying initiation and possibly even mite progeny mortality all together, thereby limiting the reproductive success of the mite. This hypothesis needs further investigation with detailed observations on mite reproduction in relation to the cuticular compounds described.

Based on the results of this study, neither hygienic behaviour nor grooming behaviour can be considered characteristics responsible for the mite tolerance observed in this surviving honey bee population in Sweden. Therefore, selection for these traits was probably not as important as traits related to mite reproduction for their survival with Varroa mites. This is an important observation considering the attention mite-resistant breeding programmes put towards these behavioural traits (Büchler et al. 2010; Rinderer et al. 2010). Furthermore, expressions of these behavioural traits are difficult to properly determine. The type of damage recorded for grooming behaviour included mutilated legs and dorsal shields as well as dimples in the dorsal shields. The latter has recently been shown to also result from birth defects (Davis 2009), and therefore the actual damages caused by bees may have been overestimated in this study. Bees can also damage already-dead mites (Rosenkranz et al. 1997), and the actual level of bee damages to vital mites is difficult to estimate from debris observations.

Table I. Means with standard errors, $F$ values and $P$ values for the differences in the proportions of infertile mites, dead progeny, absence of male progeny, delayed egg-laying and the average fecundity of mother mites, between surviving $(n=23)$ and control colonies $(n=21)$.

\begin{tabular}{|c|c|c|c|c|c|}
\hline & Infertility & Dead progeny & $\begin{array}{l}\text { Absence of male } \\
\text { progeny }\end{array}$ & $\begin{array}{l}\text { Delayed egg- } \\
\text { laying }\end{array}$ & Fecundity \\
\hline $\begin{array}{l}\text { Surviving colonies } \\
\bar{x} \pm \mathrm{SE}\end{array}$ & $0.08 \pm 0.01$ & $0.16 \pm 0.03$ & $0.07 \pm 0.01$ & $0.20 \pm 0.02$ & $3.74 \pm 0.09$ \\
\hline $\begin{array}{l}\text { Control colonies } \\
\bar{x} \pm \mathrm{SE}\end{array}$ & $0.04 \pm 0.01$ & $0.07 \pm 0.01$ & $0.03 \pm 0.01$ & $0.05 \pm 0.01$ & $4.26 \pm 0.08$ \\
\hline$F$ values & $F_{(1,41.6)}=5.34$ & $F_{(1,41.9)}=8.77$ & $F_{(1,41.7)}=7.21$ & $F_{(1,41)}=27.85$ & $F_{(1,40.2)}=19.99$ \\
\hline$P$ values & $P=0.0259$ & $P=0.0050$ & $P=0.0104$ & $P<0.0001$ & $P<0.0001$ \\
\hline
\end{tabular}


The amounts of adult bees, worker brood and drone brood were significantly lower in the surviving colonies compared with the control colonies. Since mites reproduce in the brood cells with preference for drone brood (Fuchs 1990), the reduced amounts of brood availability, in particular drone brood, in the surviving population consequently limits the reproductive opportunities for the mites. Hence, reduced colony size may be an adaptive characteristic of the surviving colonies to limit the mite population growth rate. In addition, it was clear that the smaller colony size of the surviving population was not a symptom of mite infestation since no statistically significant effects were observed on colony size from the mite infestation rates. Inbred honey bee colonies can also result in reduced colony size and since an inbreeding potential exists in the surviving colonies from Gotland due to their isolation, the level of inbreeding in this population should be investigated.

The control colonies were not treated in the fall of 2008 and by July 2009 the average mite infestation rate between the surviving and control colonies were nearly the same. However, by late September, the mite population in the surviving colonies was significantly lower compared with the control colonies. This is congruent with earlier reports on this surviving population by Fries and Bommarco (2007) who showed mite infestation rates $82 \%$ lower in surviving colonies compared with the control colonies in the fall. Our results, however, could not confirm their hypothesis that brood attractivity could possibly play a role in the mite tolerance of this population. Although mite population growth rate was higher in control colonies, surviving colonies still had high rates of mite infestation and showed clinical symptoms of viral infections. Another potential survival mechanism in this population that should be investigated is a possible heightened individual immune response to the viral infections vectored by Varroa mites.

In conclusion, this study presents colonylevel characteristics in a population of surviving honey bee colonies that limit the mite population growth by either suppressing mite reproductive success or limiting mite reproductive opportunities by reduced brood production. Although the exact mechanisms behind these traits are not yet identified, the information collected from this investigation is a step forward towards understanding the adaptive processes of mite tolerance in honey bee colonies. The only documented sustainable tolerance to $V$. destructor mite in European honey bees are of colonies that have not been selected by humans but that have been exposed to natural selection pressures. Our current direction is to compare our data with other Varroa mite-tolerant European honey bee populations to gain a deeper understanding of the host-parasite interactions in such stable relationships.

\section{ACKNOWLEDGMENTS}

Åke Lyberg is thanked for providing excellent field sites and beekeeping support. Financial support was provided by the Montagu Foundation Switzerland, within the SAVE project, the EU-funded 7th Framework project BEE DOC, Grant Agreement 244956, and Jordbruksverket for beekeeping and maintaining the original population of bees.

Caractéristiques des colonies d'abeilles (Apis mellifera) en Suède survivant à une infestation de Varroa destructor.

Varroa destructor / Apis mellifera / sélection naturelle / intéraction hôte-parasite / adaptation

Eigenschaften von Bienenvölkern (Apis mellifera) in Schweden, die Varroa destructor Infektionen überleben.

Varroa destructor / Apis mellifera / Natürliche Selektion / Toleranz / Wirt-Parasit Wechselwirkung

\section{REFERENCES}

Allen, M., Ball, B. (1996) The incidence and world distribution of honey bee viruses. BeeWorld. 77, 141-162 
Allsopp, M. (2006) Analysis of Varroa destructor infestation of southern African honey beepopulations. MS Thesis, University of Pretoria, Pretoria, South Africa

Allsopp, M., Govan, V., Davison, S. (1997) Bee health report: Varroa in South Africa. Bee World. 78, 171-174

Bogdanov, S., Kilchenmann, V., Imdorf, A. (1998) Acaricide residues in some bee products. J. Apic. Res. 37, 57-67

Bienefeld, K., Zautke, F., Pronin, D., Mazeed, A. (1999) Recording the proportion of damaged Varroa jacobsoni Oud. in the debris of honey bee colonies. Apidologie 30, 249-256

Boecking, O., Spivak, M. (1999) Behavioural defences of honey bees against Varroa jacobsoni Oud. Apidologie 30, 141-158

Boot, W.J., Calis, J.N.M., Beetsma, J. (1993) Invasion of Varroa jacobsoni into honey bee brood cells: a matter of chance or choice? J. Apic. Res. 32, 167-174

Büchler, R., Berg, S., Le Conte, Y. (2010) Breeding for resistance to Varroa destructor in Europe. Apidologie 41, 393-408

Calis, J.N.M., Fries, I., Ryrie, S.C. (1999) Population modelling of Varroa jacobsoni Oud. Apidologie 30, 111-124

Charrièr, J.D., Imdorf, A. (2002) Oxalic acid treatment by trickling against Varroa destructor: recommendations for use in central Europe and under temperate climate conditions. Bee World 82, 51-60

Corrêa-Marques, H., De Jong, D. (1998) Uncapping of worker bee brood, a component of the hygienic behaviour of Africanized honey bees against the mite Varroa jacobsoni Oud. Apidologie 29, 283-289

Crawley, M.J. (2002) Statistical computing: an introduction to data analysis using S- Plus. Wiley, Chichester

Davis, A.R. (2009) Regular dorsal dimples on Varroa destructor-damage symptoms or developmental origin? Apidologie 40, 151-162

De Jong, D., Soares, A.E.E. (1997) An isolated population of Italian bees that has survived Varroa jacobsoni infestation without treatment for over 13 years. Am. Bee J. 137, 742-745

De Jong, D., De Andrea Roma, D., Gonclaves, L.S. (1982) A comparative analysis of shaking solutions for the detection of Varroa jacobsoni on adult honey bees. Apidologie 13, 297-304

Evans, J.D., Aronstein, K., Chen, Y.P., Hetru, C., Imler, J.-L., Jiang, H., Kanost, M., Thompson, G.J., Zou, Z., Hultmark, D. (2006) Immune pathways and defence mechanisms in honey bees Apis mellifera. Insect Mol. Biol. 15, 645-656

Fries, I., Bommarco, R. (2007) Possible host-parasite adaptations in honey bees infested by Varroa destructor mites. Apidologie 38, 525-533

Fries, I., Camazine, S. (2001) Implications of horizontal and vertical pathogen transmission for honey bee epidemiology. Apidologie 32, 199-214
Fries, I., Aarhus, A., Hansen, H., Korpela, S. (1991a) Comparisons of diagnostic methods for detection of Varroa jacobsoni in honey bee (Apis mellifera) colonies at low infestation levels. Exp. Appl. Acarol. 10, 279-287

Fries, I., Aarhus, A., Hansen, H., Korpela, S. (1991b) Development of early infestations of Varroa jacobsoni in honey bee (Apis mellifera) colonies in cold climates. Exp. Appl. Acarol. 11, 205-214

Fries, I., Camazine, S., Sneyd, J. (1994) Population dynamics of Varroa jacobsoni: a model and review. Bee World. 75, 5-28

Fries, I., Hansen, H., Imdorf, A., Rosenkranz, P. (2003) Swarming in honey bees (Apis mellifera) and Varroa destructor population development in Sweden. Apidologie 34, 389-397

Fries, I., Imdorf, A., Rosenkranz, P. (2006) Survival of mite infested (Varroa destructor) honey bee (Apis mellifera) colonies in a Nordic climate. Apidologie 37, 1-7

Fuchs, S. (1990) Preference for drone brood cells by Varroa jacobsoni Oud. in colonies of Apis mellifera carnica. Apidologie 21, 193-199

Garrido, C., Rosenkranz, P. (2003) The reproductive program of female Varroa destructor mites is triggered by its host, Apis mellifera. Apidologie 35, 419-430

Garrido, C., Rosekranz, P. (2004) Volatiles of the honey bee larva initiate oogenesis in the parasitic mite Varroa destructor. Chemoecology 14, 193-197

Harbo, J.R., Harris, J.W. (2005) Suppressed mite reproduction explained by the behaviour of adult bees. J. Apic. Res. 44, 21-23

Ibrahim, A., Spivak, M. (2006) The relationship between hygienic behaviour and suppression of mite reproduction as honey bee (Apis mellifera) mechanisms of resistance to Varroa destructor. Apidologie 37, $31-40$

Imdorf, A., Bühlmann, G., Gerig, L., Kilchenmann, V., Wille, H. (1987) Überprüfung der Schätzmethode zur Ermittlung der Brutfläche und der Anzahl Arbeiterinnen in freifliegenden Bienenvölkern. Apidologie 18, 137-146

Imdorf, A., Kilchenmann, V., Maquelin, C. (1990) Optimal Ameisensäureanwendung. Schweiz. Bienenztg. 113, 378-385

Imdorf, A., Bogdanov, S., Ibáñez, O.R., Calderone, N.W. (1999) Use of essential oils for the control of Varroa jacobsoni in honey bee colonies. Apidologie 30, 209-228

Kefuss, J., Vanpouke, J., Ducos De Lahitte, J., Ritter, W. (2004) Varroa tolerance in France of Intermissa Bees from Tunisia and their naturally mated descendants: 1993-2004. Am. Bee J. 144, 563-568

Le Conte, Y., de Vaublanc, G., Crauser, D., Jeanne, F., Rousselle, J.-C., Bécard, J.-M. (2007) Honey bee colonies that have survived Varroa destructor. Apidologie 38, 566-572 
Littell, R.C., Milliken, G.A., Stroup, W.W., Wolfinger, R. D. (1996) SAS system for mixed models. SAS, Cary

Martin, S.J. (1994) Ontogenesis of the mite Varroa jacobsoni Oud. in worker brood of the honeybee Apis mellifera L. under natural conditions. Exp. Appl. Acarol. 18, 87-100

Martin, S.J. (2001) The role of Varroa and viral pathogens in the collapse of honeybee colonies: a modeling approach. J. Appl. Ecol. 38, 1082-1093

Martin, S.J., Medina, L. (2004) Africanized honeybees have unique tolerance to Varroa mites. Trends Parasitol. 20, 112-114

Medina, L., Martin, S.J., Espinosa, L.M., Ratnieks, L.F. (2002) Reproduction of Varroa destructor in worker brood of Africanized honey bees (Apis mellifera). Exp. Appl. Acarol. 27, 79-88

Millani, N., Della, V.G., Nazzi, F. (2004) (Z)-8-Heptadecene reduces the reproduction of Varroa destructor in brood cells. Apidologie 35, 265-274

Mondragon, L., Martin, S.J., Vandame, R. (2006) Mortality of mite offspring: a major component of Varroa destructor resistance in a population of Africanized bees. Apidologie 37, 67-74

Moosbeckhofer, R. (1992) Beobachtungen zum Auftreten beschädigter Varroamilben innatürlichen Totenfall bei Völkern von Apis mellifera carnica. Apidologie 23, 523-531

Moretto, G., Goncalves, L.S., De Jong, D. (1995) Analysis of the F1 generation, descendants of Africanized bee colonies with differing defense abilities against the mite Varroa jacobsoni. Rev. Brazil. Genet. 18, 177-179

Nordström, S., Fries, I., Aarhus, A., Hansen, H., Korpela, S. (1999) Virus infections in Nordic honey bee colonies with no, low or severe Varroa jacobsoni infestations. Apidologie 30, 475-484

Palacio, M.A., Figini, E.E., Ruffinengo, S.R., Rodriguez, E.M., del Hoyo, M.L., Bedascarrasbure, E.L. (2000) Changes in a population of Apis mellifera L. selected for hygienic behavior and its relation to brood disease tolerance. Apidologie 31, 471-478

Rath, W. (1999) Co-adaptation of Apis cerana Fabr. and Varroa jacobsoni Oud. Apidologie 20, 339-343

Rinderer, T.E., de Guzman, L.I., Delatte, G.T., Stelzer, J. A., Lancaster, V.A., Kuznetsov, V., Beaman, L., Watts, R., Harris, J.W. (2001) Resistance to the parasitic mite Varroa destructor in honey bees from far-eastern Russia. Apidologie 32, 381-394

Rinderer, T.E., Harris, J.W., Hunt, G.J., de Guzman, L.I. (2010) Breeding for resistance to Varroa destructor in North America. Apidologie 21, 409-424
Rosenkranz, P. (1999) Honey bee (Apis mellifera L.) tolerance to Varroa jacobsoni Oud. in South America. Apidologie 30, 159-172

Rosenkranz, P., Engels, W. (1994) Infertility of Varroa jacobsoni females after invasion into Apis mellifera worker brood as a tolerance factor against varroatosis. Apidologie 25, 402-411

Rosenkranz, P., Fries, I., Boecking, O., Stürmer, M. (1997) Damaged Varroa mites in the debris of honey bee (Apis mellifera L.) colonies with and without hatching brood. Apidologie 28, 427-437

Rosenkranz, P., Frey, E., Odemer, R., Mougel, F., Solignac, M., Locke, B. (2009) Variance of the reproduction of the parasitic mite Varroa destructor and its significance for host resistance at the individual level. Abstract 41. Apimondia congress, 15 20.09.2009, Montpellier, 96

Rosenkranz, P., Aumeier, P., Ziegelmann, B. (2010) Biology and control of Varroa destructor. J. Invert. Pathol. 103, 96-119

Sammataro, D., Untalan, P., Guerrero, F., Finley, J. (2005) The resistance of Varroa mites (Acari: Varroidae) to acaricides and the presence of esterase. Int. J. Acarol. 31, 67-74

Seeley, T.D. (2007) Honey bees of the Arnot Forest: a population of feral colonies persisting with Varroa destructor in the northeastern United States. Apidologie 38, 19-29

Solignac, M., Cornuet, J.M., Vautrin, D., Le Conte, Y., Anderson, D., Evans, J., Cros-Arteil, S., Navajas, M. (2005) The invasive Korean and Japan types of Varroa destructor, ectoparasitic mite of the Western honeybee (Apis mellifera), are two partly isolated clones. Proc. R. Soc. B. 272, 411-419

Spivak, M. (1996) Honey bee hygienic behaviour and defense against Varroa jacobsoni. Apidologie 27, 245-260

Spivak, M., Reuter, G.S. (2001) Varroa destructor infestation in untreated honey bee (Hymenoptera: Apidae) colonies selected for hygienic behaviour. J. Econ. Entomol. 94, 326-331

Sumpter, D.J.T., Martin, S.J. (2004) The dynamics of virus epidemics in Varroa-infested honey bee colonies. J. Anim. Ecol. 73, 51-63

Tarpy, D.R., Summers, J., Keller, J.J. (2007) Comparison of parasitic mites in Russian hybrid and Italian honey bee (Hymenoptera: Apidae) colonies across three different location in North Carolina. J. Econ. Entomol. 100, 258-266

Wallner, K. (1999) Varroacides and their residues in bee products. Apidologie 30, 235-248 